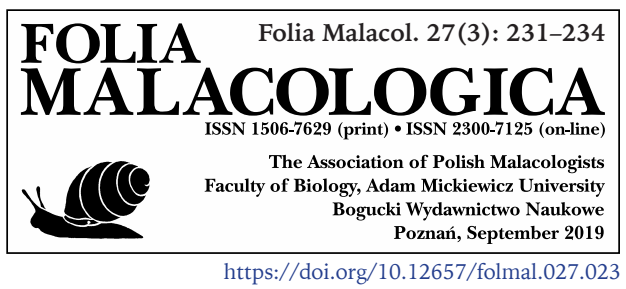

SHORT COMMUNICATION

\title{
NEW RECORDS OF THE INVASIVE BIVALVE DREISSENA POLYMORPHA (PALLAS, 1771) (BIVALVIA: DREISSENIDAE) IN THE CARPATHIAN MOUNTAINS, POLAND
}

\author{
KAMILA S. ZAJĄC ${ }^{1}$, MACIEJ BONK²* \\ ${ }^{1}$ Institute of Environmental Sciences, Jagiellonian University, Gronostajowa 7, 30-387 Cracow, Poland \\ (e-mail: kamila.zajac12@gmail.com); (1) https://orcid.org/0000-0002-4132-3311 \\ ${ }^{2}$ Institute of Nature Conservation, Polish Academy of Sciences, al. Adama Mickiewicza 33, 31-120 Cracow, \\ Poland (e-mail: bonk.maciej@gmail.com); (i) https://orcid.org/0000-0003-4093-2542 \\ *corresponding author
}

ABSTRACT: The zebra mussel, Dreissena polymorpha (Pallas, 1771) is a widely distributed invasive species in Europe. However, in Poland it is unevenly distributed and considered rare in Southern Poland. To date, only one record of the species has been known from the Polish Carpathians. In this study we report new records of zebra mussels from the area of the Żywiecka Basin. In the localities studied empty shells as well as live individuals in variable size and developmental stage were detected, which indicate that in these locations zebra mussel populations are stable.

KEY WORDS: Dreissenidae, Carpathians, new sites, zebra mussel

The zebra mussel, Dreissena polymorpha (Pallas, 1771) is one of the two representatives of the Dreissenidae family in Poland (PIECHOCKI \& WAWRZYNIAK-WYDROWSKA 2016). It is a mediumsize bivalve with dimensions $20-40 \mathrm{~mm}$ (length) $\times 11-18 \mathrm{~mm}$ (height) $\times 12-23 \mathrm{~mm}$ (width); the shell is triangular in outline (PIECHOCKI \& WAWRZYNIAKWYDROWSKA 2016). It inhabits mainly flowing and free-standing reservoirs and both freshwater and brackish waters. Before glaciation $D$. polymorpha was present along the Volga river and in Central Europe, but during the last glacial period it went extinct almost completely in the whole area of its distribution (ANDRUSOV 1897, WESENBERG-LUND 1939, ZHADIN 1946, MoRduCHAI-BOLTOVSKOI 1965). The recent native range of $D$. polymorpha includes the PontoCaspian region with the basins of Black, Caspian and Aral Seas (GOLLASCH \& LEPPÄKOSKI 1999), but today, the zebra mussel is widely distributed across Europe. It was introduced accidentally by human activity to north-western areas of Russia, Austria, Czech Republic, Denmark, Estonia, Finland, Germany, Latvia, Lithuania, Great Britain and Ireland. It is present also in Sweden (reported in 1924), Italy (1977) and Spain (2001) (ZAIKO \& OLENIN 2006). In Poland $D$. polymorpha appeared in the first half of nineteenth century in Vistula, Szczecin Lagoon and also in Suwałki Lakes in the Augustów Canal (PIECHOCKI \& DYDUCH-FALNIOWSKA 1993).

$D$. polymorpha has a huge significance in aquatic environments and is considered as a species of special economic importance. It affects native species, as the presence of zebra mussel in reservoirs may lead to a decrease in Unionidae species richness. Disappearance of Unionidae due to the presence of $D$. polymorpha was observed in many rivers and lakes of North America (HEBERT et al. 1991, NALEPA et al. 1996, RicCiARDI et al. 1996, HALLAC \& MARSDEN 2000). Moreover, the zebra mussel can attach to the shell surface of Unionidae representatives, such as 
Anodonta anatina (LEWANDOWSKI 1976). D. polymorpha grows in underwater devices which causes technical problems or even preventing them from proper functioning which is burdensome for this large industry (STAŃCZYKOWSKA \& LEWANDOWSKI 2011). Besides the above mentioned problems associated with this invasive species, the zebra mussel is often preferred as a food source of many species of crayfish, fishes (Rutilus rutilus, Anguilla anguilla, Abramis bra$m a$ ), birds (Fulica atra, Aythya fuligula, A. ferina) and also mammals (Ondatra zibethicus) (STEMPNIEWICZ 1974, PREJS et al. 1990, MOLlOY et al. 1997).

Although, PIECHOCKI \& DYDUCH-FALNIOWSKA (1993) stated that $D$. polymorpha is present mainly in the area of Pomerania, Greater Poland Province and Mazury Lake District, recent studies have shown that $D$. polymorpha may be present in many other localities in lowland parts of Poland (STAŃCZYKOWSKA \& LEWANDOWSKI 2011, PIECHOCKI \& WAWRZYNIAKWYDROWSKA 2016). However, in the case of the Carpathians, the only known locality comes from a single site in the Dunajec River drainage (PIECHOCKI \& DYDUCH-FALNIOWSKA 1993). However, no precise locality is available from that study. This contribution describes new sites of D. polymorpha from Żywiecka Basin (Western Carpathians).

D. polymorpha was detected in the Tresna Reservoir $\left(49^{\circ} 43^{\prime} 31.70^{\prime \prime} \mathrm{N}, 19^{\circ} 12^{\prime} 26.20^{\prime \prime} \mathrm{E}\right)$ during a crayfish survey on 5 October 2018. Mussels were found in seven sites distributed relatively evenly around the reservoir on both western and eastern banks. Mussels were attached to rip rap embankments, isolated stones and macrophytes (Fig. 1). Several individuals were attached to U. pictorum shells and Orconectes limosus carapaces. Feeding of $O$. limosus on $D$. polymorpha was also noted. As surveys were crayfish oriented, no information on abundance was obtained, but $D$. polymorpha was easily detected within several minutes of observations. From July to October 2018 crayfish surveys were conducted also in five $200 \mathrm{~m}$ sections of the Sola River up to $6 \mathrm{~km}$ from its inflow into Tresna Reservoir and in 11 sections up to $5 \mathrm{~km}$ of other, smaller streams (Łękawka, Żylica and three unnamed watercourses) feeding the reservoir. We did not record D. polymorpha in any of them. Mussel dedicated surveys are necessary before this absence is confirmed. D. polymorpha was also detected in Sola River $\left(49^{\circ} 45^{\prime} 45.7^{\prime \prime} \mathrm{N}, 1^{\circ} 12^{\prime} 36.5^{\prime \prime} \mathrm{E}\right)$ in Czernichów village and in Międzybrodzkie Lake $\left(49^{\circ} 46^{\prime} 16.1^{\prime \prime} \mathrm{N}\right.$, $\left.19^{\circ} 12^{\prime} 33.8^{\prime \prime} \mathrm{E}\right)$. In these two localities living zebra mussels of different sizes and developmental stages were observed as well as empty shells.

According to the map of $D$. polymorpha distribution in Poland published by PIECHOCKI \& DYDUCHFALNIOWSKA (1993), the zebra mussel is rare or absent in mountain areas, in both Carpathians and Sudetes. The southernmost known locality of this species was noted near Rożnów village in southern Poland (PIECHOCKI \& DYDUCH-FALNIOWSKA 1993). The localities described in this study are thus the first of $D$. polymorpha from the Polish Carpathian Mts for 25 years. The presence of empty shells and alive individuals of various sizes suggests that these populations are relatively stable. Despite the evidence the

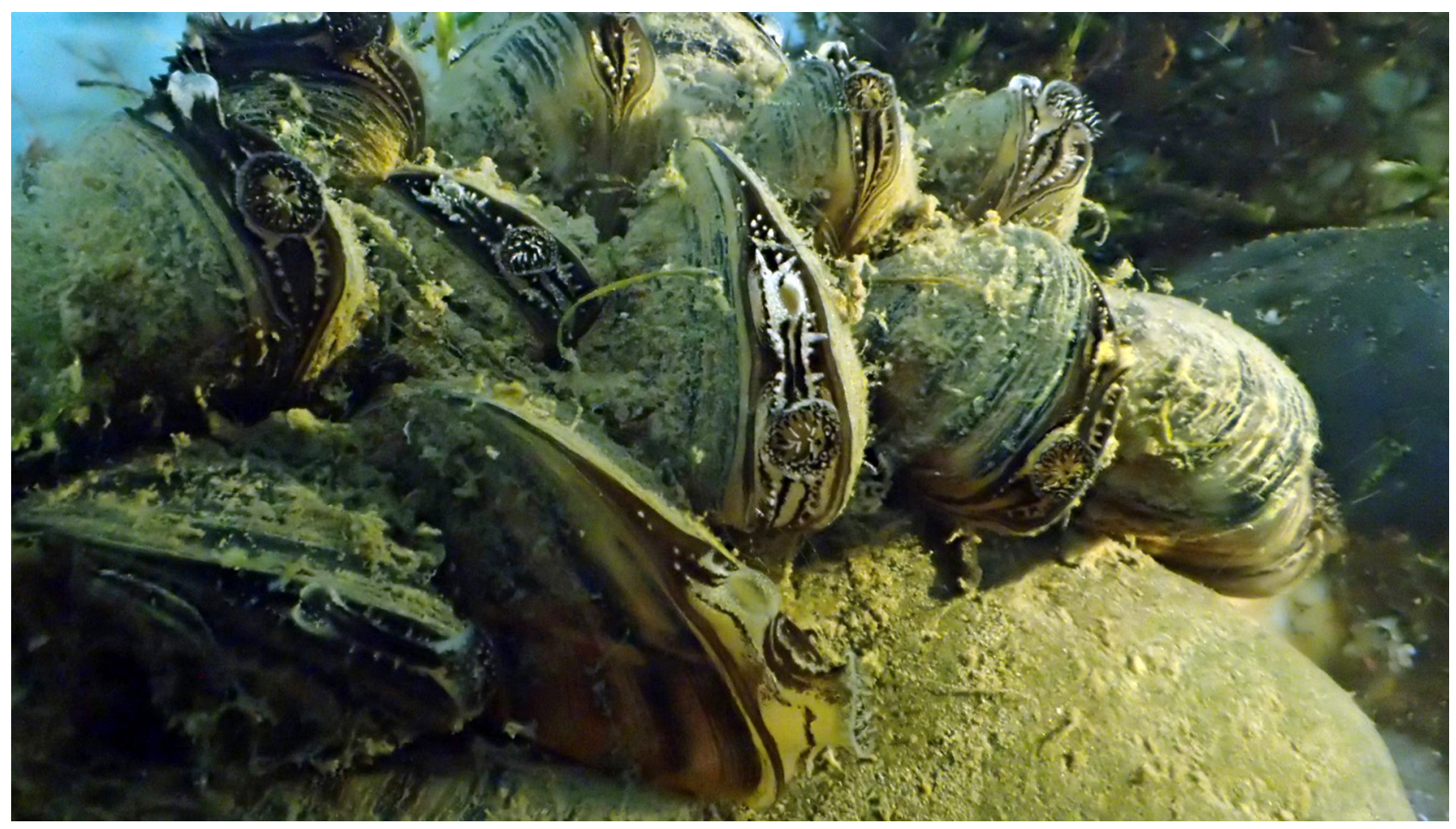

Fig. 1. The zebra mussels Dreissena polymorpha (Pallas, 1771) from the Tresna Reservoir 
range of $D$. polymorpha is increasing, there is also evidence that it may disappear in some water reservoirs. This may be explained as an effect of increasing water pollution and eutrophication which suggest that zebra mussel is sensitive to such environmental changes (PIECHOCKI \& WAWRZYNIAK-WYDROWSKA 2016). Additionally, building-up of shores, destruction of vegetation and anthropogenic transformations of lake littoral may also cause the disappearance of D. polymorpha populations (STAŃCZYKOWSKA 1994, STAŃCZYKOWSKA \& LEWANDOWSKI 2011). Zebra mussels occurring in high density in particular locations may constitute one of the most important elements of cleansing highly-fertilized water reservoirs from over-developed phytoplankton (PIESIK 1992).

Over the years the expansion of $D$. polymorpha was greatly facilitated because of passive mussel transport. Zebra mussel can attach by byssus to drifting wood logs, barges or rafts and it was thus able to cover long distances by river beds and inhabit new places. Additionally, colonization into new areas may be easier because of presence of planktonic veligers

\section{REFERENCES}

ANDRUSOV N. I. 1897. Iskopaemye i zhivushchye Dreissenidae Evrazii. Trudy Sankt-Petersburskogo Obshchestva Estestvoispytyvaniya 25: 1-683.

GOLLASCH S., LEPPÄKOSKI E. (eds). 1999. Initial risk assessment of alien species in Nordic Coastal Waters. Nordic Council of Ministers, Copenhagen.

Hallac D. E., Marsden J. E. 2000. Differences in tolerance to and recovery from zebra mussel (Dreissena polymorpha) fouling by Elliptio complanata and Lampsilis radiata. Canadian Journal of Zoology 78: 161-166. https:// doi.org/10.1139/z99-195

Hebert D. N., Wilson C. C., Murdoch M. H., Lazar R. 1991. Demography and ecological impacts of the invading mollusc Dreissena polymorpha. Canadian Journal of Zoology 69: 405-409. https://doi.org/10.1139/z91063

LEWANDOWSKI K. 1976. Unionidae as a substratum for Dreissena polymorpha (Pall.). Polskie Archiwum Hydrobiologii 23: 409-420.

Molloy D. P., KaratayeV A. Y., Burlakova L. E. KURANDINA D. P., LARUELLE F. 1997. Natural enemies of zebra mussels: predators, parasites, and ecological competitors. Reviews in Fisheries Science 5: 27-97. https://doi.org/10.1080/10641269709388593

MORDUCHAI-BOLTOVSKOI F. D. 1965. Proischozhdenie i rasprostranenie polimorfnoy drejsseny. In: Soveshchanie po biologii drejsseny i zashchite gidrotechnicheskich sooruzheniy ot ee obrastaniy. Institut Biologii Vnutrennich Vod, Akademija Nauk SSSR, Togliatti.

NALePA T. F., Hartson D. J., Gostenik G. W., FANSLOW D. L., LANG G. A. 1996. Changes in the freshwater mussel community of Lake St. Clair: from Unionidae in zebra mussel life cycle which can easily give rise to new populations (PIECHOCKI \& WAWRZYNIAKWYDROWSKA 2016).

In our study we confirmed the presence of $D$. polymorpha in localities described above which at the same time constitute the second ever record of this species from Polish Carpathians. Previous faunistic studies conducted in Żywiec town (Southern Poland) did not show the presence of this species in this area (ZAJACC 2014). However, D. polymorpha may occur in other reservoirs in Carpathians and further studies on its distribution and expansion within these terrains are needed. Furthermore, presence of this mussel in submontane reach of Sola River suggests that spreading along water courses may at least occasionally occur.

\section{ACKNOWLEDGEMENT}

Studies were partially supported by the Institute of Nature Conservation, Polish Academy of Sciences, through its statutory fund and a grant for young scientists and Ph.D. candidates. to Dreissena polymorpha in eight years. Journal of Great Lakes Research 22: 354-369. https://doi.org/10.1016/ S0380-1330(96)70961-9

Piechocki A., Dyduch-FalniowsKa A. 1993. Mięczaki (Mollusca). Małże (Bivalvia). Fauna słodkowodna Polski 7A. Wydawnictwo Naukowe PWN, Warszawa.

PIECHOCKI A., WAWRZYNIAK-WydroWsKA B. 2016. Guide to freshwater and marine Mollusca of Poland. Bogucki Wydawnictwo Naukowe, Poznań.

PIESIK Z. 1992. Możliwość biologicznej rekultywacji Zalewu Szczecińskiego. Szczeciński Rocznik Naukowy 1: 23-36.

PREJS A., LEWANDOWSKI K., STAŃCZYKOWSKA-PIOTROWSKA A. 1990. Size-selective predation by roach (Rutilus rutilus) on zebra mussel (Dreissena polymorpha): field studies. Oecologia 83: 378-384. https://doi.org/10.1007/ BF00317563

RicCIARDi A., WHORISKEY F. G., RASMUSSEN J. B. 1996. Impact of the Dreissena invasion on native unionid bivalves in the upper St. Lawrence River. Canadian Journal of Fisheries and Aquatic Sciences 53: 14341444. https://doi.org/10.1139/f96-068

STAŃCZYKOWSKA A. 1994. Long-term changes in some Dreissena polymorpha (Pall.) populations in Poland. Verhandlungen des Internationalen Verein Limnologie 25: 2352-2354. https://doi.org/10.1080/03680770.19 92.11900636

STAŃCZYKOWSKA A., LEWANDOWSKI K. 2011. Dreissena polymorpha - racicznica zmienna In: GŁOWACIŃsKI Z. (ed.) Gatunki obce w faunie Polski. II. Zagadnienia problemowe. Wyd. Instytutu Ochrony Przyrody PAN w Krakowie, Kraków, pp. 133-140. 
STEMPNIEWICZ L. 1974. The effect of feeding of coot (Fulica atra L.) on the character of the shoals of Dreissena polymorpha Pall. in the Lake Gopło. Acta Universitatis Nicolae Copernici, Seria Matematyczno-Przyrodnicza 34: 84-103.

WESENBERG-LUND C. 1939. Biologie der Süsswassertiere. Springer Verlag, Wien.

ZAIKO A., OLENIN S. 2006. NOBANIS - Invasive alien species fact sheet - Dreissena polymorpha. Database of North European and Baltic Network on Invasive Alien Species - NOBANIS. Available online at www.nobanis. org (accessed: 07-04-2019).
ZAJĄC K. 2014. The mollusc fauna of Żywiec town (Southern Poland). Folia Malacologica 22: 209-220. https://doi.org/10.12657/folmal.022.013

ZHADIN V. I. 1946. Stranstvuyushchaya rakushka dreissena. Priroda 5: 29-37.

Received: May 9th, 2019

Revised: August 7th, 2019

Accepted: August 14th, 2019 Published on-line: September 14th, 2019 